\title{
Main actors in provision of fiction e-books in a small language market: A Swedish case
}

\author{
Birgitta Wallin* and Elena Maceviciute \\ Swedish School of Library and Information Science, University of Borås, Borås, Sweden
}

\begin{abstract}
One of the consequences of the "small language" phenomenon is that the Swedish book industry is prey to the negative effects of globalization, since books have an international market and a Swedish multilingual citizen can buy e-books from international online booksellers. Publications in the local language are potentially in competition with books in English, and a local publisher or bookseller is competing with international publishers and Amazon.com
\end{abstract}

Keywords: E-books, small language market

\section{Introduction}

Today, a major technological revolution is taking place that affects every element in the total publishing, distribution and use system.

The distribution chain has changed markedly since the arrival of the e-book. Other actors than the traditional booksellers have become distributors of e-books. Large chains of bookshops, such as Borders and Barnes \& Noble, are forced to shut down many of their shops. Libraries face the rivals on the Internet that started loan of e-books for small subscription fees.

An outline of the present system is shown in Fig. 1. An author submits a manuscript to a publisher; the publisher assesses the market potential of the book and a contract is signed between author and publisher. The publisher produces the book, subcontracting the physical production to a printing company, or using in-house printing capacity, and retails it through booksellers. Libraries buy books through a combination of specialist library supply firms and local booksellers and individual readers either borrow from libraries or buy directly from bookshops. The alternative lines of interaction are the dotted red lines and some of the factors that affect each player.

This basic model has variants, of course: some publishers own bookshop chains, and some sell directly to the public and to libraries. The invention of the e-book, however, has the potential fundamentally to change not only the technology of book production but also how authors decide to publish their work and how readers decide to read. It also has the potential to remove the small bookseller completely from the system, although it is possible that large chains will survive by becoming more diverse. It has a potential to obliterate all other links in the chain leaving a bare carcass of direct communication between the author and the reader, though it is more likely that other mediators will enter the changing book sector as is already happening [5].

\footnotetext{
*Corresponding author. E-mail: birgitta.wallin@hb.se.
} 


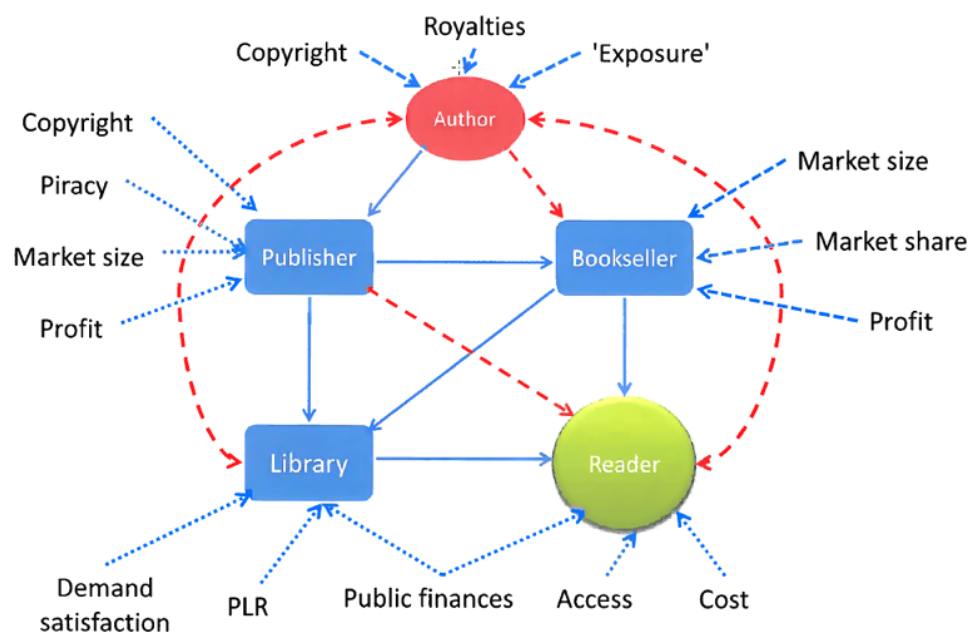

Fig. 1. Interactions in the e-book field (Wilson, [4]). (Colors are visible in the online version of the article; http://dx.doi.org/ 10.3233/ISU-140754.)

\section{Small language and Swedish e-book fiction}

The situation in Sweden with regard to the successful introduction of e-books into the national book culture is complicated by a number of factors. Sweden is a so-called small language market, but with a population that are technologically literate and, more or less, proficient in English and other languages. Therefore, many Swedes buy e-books in foreign languages provided by international booksellers. Swedish publishers are affected by piracy and the availability of free download sites as the rest in the world.

\section{Swedish fiction e-book producers}

A recent study [2] notes that publishing is particularly vulnerable to the impact of the e-book because of the 'long tail' nature [1] of the market for books. The arrival of the e-book means that it is now easier to satisfy low demand because an e-book can be produced on demand, rather than necessitating a print run that might find few buyers. Dyck and Sturgess [2] point to the disintermediation potential of the e-book, with authors selling directly to readers.

Swedish publishers of e-books are the largest in the country, but a number of small publishers sell their e-products on publishers' websites or through the major Internet booksellers. A variety of projects and organisations, such as libraries, museums, and archives digitize older books and disseminate them free of charge. E.g., the catalogue of the Project Runeberg lists 2762 titles of old books digitised with the help of volunteers. The website runeberg.org redirects authors who wish to self-publish to Project Gutenberg (self.gutenberg.org).

\section{Swedish fiction e-book sellers}

E-books are big news for libraries in the West reporting significantly increased demand. Their impact elsewhere appears to be somewhat less, but can be expected to grow as the number of devices that can be 
used for access increases. But as the music industry attempted to limit the distribution of music tracks, so book publishers seek to maximise the return on investment in authors and minimise the possible exposure to piracy. There are other social and cultural factors that influence the slower or quicker rate of e-book acceptance in different countries and regions. Swedish e-books do not enjoy the same status of cultural objects as printed books. They are treated as software and/or service, therefore the VAT on them is as high as $25 \%$ (compare with $6 \%$ for print books). This is supposed to be one of the main factors slowing down their introduction to the market.

In Sweden, the sale of e-books is under control of four major publishers running the Elib network bookseller. Elib is the main channel of distribution for their e-books but also sells e-books produced by other publishers. There are other Internet sellers of e-books, such as Adlibris and Bokus. Adlibris has developed an e-reader Letto for Swedish books and Bokus provides Dito software for e-book reading. Swedish fiction can be bought through AppStore, Amazon and other international Internet sellers.

\section{Swedish fiction e-books in public libraries}

The provision of e-books to libraries in Sweden is dominated by one provider, Elib. The model that Elib offers to libraries includes a firm sum for each loan of an e-book (20 SEK = approx. €2.4). The books are always loaned for 28 days and only for offline reading. The access through local libraries is advertised not only through the websites of public libraries, but also on the website of Elib. There it is displayed prominently. The loans of e-books through libraries are free of charge to library users and this is also advertised on the Elib website with explanation that a reader just needs to acquire a library card for easy download of e-books.

This is an attractive model for readers and in comparison to more restricted models of e-books provision to libraries, as it does not limit multiple use of an e-book or provide other severe restrictions of use. Part of the offered collection is available with watermarks instead of restrictive DRM. Since April 2013, the company also offers a streaming service ElibU for school libraries and schools; see Table 1.

However, the Elib model is expensive for library loans of popular titles and prevents libraries from managing their collections effectively. Many Swedish public libraries were forced to stop loans of ebooks as the part of the budget allocated for the service was used up. The negotiations between librarians and publishers ended without results and at present the Association of Regional and Local Authorities started this process again on behalf of public libraries. In addition, the Library Law that is in force from October 2014 demands that public libraries provide access to all literature regardless of format free of charge.

In 2013, several new actors, such as, Publit (distributor) and Axiell (digital service developer for libraries - with their platform Atingo), Adlibris and Bokus (internet book shop) with Dito for e-books have entered e-book market and started providing books to libraries. Atingo offers a differentiated price for older and new books, but so far only few libraries have adopted their service (with Stockholm City Library taking the initiative) [3].

Table 1

Sales vs library loans of e-books

\begin{tabular}{ccc}
\hline Year & Sales of e-book titles (Elib) & E-book loans from public libraries \\
\hline 2010 & 1,969 & 466,000 \\
2011 & 3,018 & 647,000 \\
2012 & 4,125 & - \\
\hline
\end{tabular}




\section{Conclusion}

The diversification of the actors present in the market of Swedish fiction e-books is increasing especially in commercial and public distribution system. Though at present the power lies mainly with the publishers who dictate the conditions of e-book dissemination, the dynamics of the situation make it rather unpredictable. Public libraries are major customers for e-books and book loans through libraries are increasing more rapidly than e-book sales. Thus libraries acquire more bargaining power with the producers who cannot abandon e-books altogether because of the competition from the international book distributors.

\section{References}

[1] C. Anderson, The Long Tail: Why the Future of Business is Selling Less of More, Hyperion, New York, 2008.

[2] J. Dyck and T. Sturgess, The emerging importance of the e-book and its impact on publishing 2012, available at: http://teresasturgess.files.wordpress.com/2013/01/the_emerging_importance_of_the_e-book_and_its_impact_on_ publishing_dyck_and_sturgess1.pdf.

[3] E. Maceviciute and M. Borg, The current situation of e-books in academic and public libraries in Sweden, in: International Conference on Publishing: Trends and Contexts, Pula, Croatia, 2013, pp. 6-7.

[4] T.D. Wilson, The e-book phenomenon: a disruptive technology, in: International Conference on Publishing: Trends and Contexts, Pula, Croatia, 6-7 December, 2013.

[5] T.D. Wilson et al., E-book in a Small Language Culture: Project Description, University of Borås, Borås, 2012. 